\title{
Caracterização genética de Euphorbia heterophylla resistente a herbicidas inibidores da acetolactato sintase
}

\author{
Larissa Macedo Winkler (2), Ribas Antônio Vidal(2) e José Fernandes Barbosa Neto(2)
}

\begin{abstract}
Resumo - O aumento do número de plantas daninhas resistentes aos herbicidas inibidores da enzima acetolactato sintase é um tema abordado com freqüência por produtores e comunidade científica. No Brasil, nove espécies já foram documentadas por apresentarem tal problema. O objetivo deste trabalho foi determinar a diversidade genética de populações de leiteira (Euphorbia heterophylla L.) resistentes aos herbicidas inibidores da enzima acetolactato sintase. Quarenta populações de plantas oriundas de sementes coletadas em áreas do Estado do Rio Grande do Sul, Brasil, com suspeita de resistência, foram selecionadas, a partir da aplicação prévia de herbicidas com este mecanismo de ação em casa de vegetação. Vinte plantas de cada população serviram de amostra para a extração de DNA. Trinta marcadores de polimorfismo de DNA amplificado ao acaso (RAPD) foram selecionados, cada um com 10 oligonucleotídeos de seqüência arbitrária. Na análise de agrupamento, cujo coeficiente médio de similaridade foi de $40 \%$, as populações foram separadas em sete grupos. As populações dos municípios de Pontão, Augusto Pestana e Não-me-Toque foram consideradas geneticamente diferentes. Há variabilidade genética relacionada à resistência do herbicida entre as populações de E. heterophylla que ocorrem no planalto do Estado do Rio Grande do Sul.
\end{abstract}

Termos para indexação: planta daninha, variação genética, polimorfismo genético, inibidor de enzima.

Genetic characterization of Euphorbia heterophylla resistant to acetolactate synthase-inhibiting herbicides

\begin{abstract}
The increase of the number of weed plants resistant to enzyme acetolactate sintase (ALS)-inhibiting herbicides of is a subject frequently discussed by farmers and scientific community. In Brazil, nine species were registered with such problem. The objective of this work was to determine the genetic diversity of wild poinsettia (Euphorbia heterophylla L.) ALS-resistant populations. Forty populations deriving from seeds collected in areas of the State of Rio Grande do Sul, Brazil, with resistance suspicion, were selected from the previous application of herbicides in greenhouse. Twenty plants of each population were sampled for DNA extraction. Analysis of 30 random amplified polymorphic DNA (RAPD) markers were performed. Each marker had 10 oligonucleotide of arbitrary sequence. On the grouping analysis, the overall coefficient of similarity was $40 \%$ and the populations were separated in seven groups. The populations of the counties of Pontão, Augusto Pestana and Não-me-Toque were genetically different. There is genetic variability related to herbicide resistence among E. heterophylla populations from plateaus of the State of Rio Grande do Sul.
\end{abstract}

Index terms: weeds, genetic variation, genetic polymorphism, enzyme inhibitors.

\section{Introdução}

A espécie Euphorbia heterophylla L., conhecida como leiteira ou amendoim-bravo, é uma planta

\footnotetext{
(1) Aceito para publicação em 9 de julho de 2003.

(2) Universidade Federal do Rio Grande do Sul, Fac. de Agronomia, Dep. de Plantas de Lavoura, Caixa Postal 15.100, CEP 90001-970 Porto Alegre, RS. E-mail: lari1973@ig.com.br, ribas.vidal@ufrgs.br, jfbn@ufrgs.br
}

daninha alógama cujo centro de origem está compreendido na região Brasil-Paraguai (Kissmann \& Groth, 1992). Essa espécie está amplamente distribuída no centro-sul do Brasil, constatando-se sua presença em $74 \%$ das áreas de soja do planalto do Estado do Rio Grande do Sul (Vidal \& Winkler, 2002). Cada dez plantas de E. heterophylla $/ \mathrm{m}^{2}$ reduz em $7 \%$ o rendimento de grãos quando o período de convivência com a cultura ocorre durante todo o ciclo (Chemale \& Fleck, 1982). 
O controle de E. heterophylla é realizado principalmente com herbicidas inibidores das enzimas acetolactato sintase (ALS) e protoporfirinogênio oxidase (PROTOX) (Vidal \& Merotto Júnior, 2001). Contudo, na última década, identificou-se nessa espécie biótipos resistentes aos inibidores de ALS, nos estados do Rio Grande do Sul, Paraná, São Paulo e Mato Grosso do Sul e no Paraguai (Gazziero et al., 1998; Heap, 2002; Vidal \& Winkler, 2002).

Os fatores que favorecem a seleção de biótipos resistentes envolvem características relacionadas às plantas daninhas, aos herbicidas e às práticas culturais. Uma das características inerentes às plantas daninhas é a grande diversidade genética. Esta, de maneira geral, favorece a seleção de indivíduos resistentes aos herbicidas em virtude da maior probabilidade de se encontrar, na população, alelo que confere resistência ao produto utilizado. Pelo mesmo motivo, grandes infestações favorecem o aumento dos riscos de seleção para resistência (Vidal \& Merotto Júnior, 2001; Winkler et al., 2002).

A diversidade genética existente em uma população é o resultado do processo de evolução natural da espécie que a compõe, em função da variação mendeliana, hibridação interespecífica e poliploidia. Cinco estádios são empregados atualmente na tentativa de explicar a evolução da resistência: 1) a eliminação de todos os biótipos altamente suscetíveis, o que favorece os biótipos ditos tolerantes e resistentes; 2) eliminação de todos os biótipos, exceto os resistentes; 3 ) seleção destes biótipos dentro de uma população com elevada tolerância; 4) intercruzamento dos biótipos sobreviventes, gerando indivíduos resistentes que serão selecionados; 5) segregação e recombinação dos genes (Mortimer, 1998 citado por Vargas et al., 2001; Winkler et al., 2002).

A resistência aos inibidores de ALS em E. heterophylla é conferida por um único gene dominante e com herança nuclear (Vargas et al., 1999). A caracterização genética das populações resistentes aos inibidores de ALS permitirá investigar se a resistência ocorreu simultaneamente em diversos locais ou se houve um evento de seleção que se disseminou em diversas áreas do país por meio da dispersão de pólen/semente.

Marcadores moleculares do tipo RAPD (polimorfismo de DNA amplificado ao acaso) permitem caracterizar plantas e microrganismos e avaliar a diversidade genética entre indivíduos de uma mesma espécie ou de diferentes espécies (Williams et al., 1990).

A variação genética em Poa annua L., causada pela pressão de seleção proveniente da aplicação de herbicidas, também foi avaliada por RAPD (Sweeney \& Danneberger, 1995). A mesma técnica foi usada para detectar diferenças de tolerância de Echinochloa crus-galli para o herbicida quinclorac (Rutledge et al., 2000) e para avaliar a influência da aplicação do herbicida na variação genética de Sinapsis arvensis L. (Moodie et al., 1997).

Marcadores moleculares de RAPD também foram utilizados para determinar a variação genética entre indivíduos de cinco populações geograficamente separadas de Euphorbia esula (Rowe et al., 1997). Os autores concluíram que a similaridade genética é maior entre indivíduos dentro de uma população e que a dispersão de pólen foi facilitada dentro e entre populações muito próximas geograficamente, contribuindo para este resultado.

O objetivo deste trabalho foi determinar a diversidade genética de populações de Euphorbia heterophylla resistentes aos herbicidas inibidores de ALS.

\section{Material e Métodos}

Frutos de diversas plantas de Euphorbia heterophylla, que apresentaram suspeita de resistência aos inibidores de ALS, foram coletados em lavouras de soja localizadas na região do planalto do Estado do Rio Grande do Sul, entre os meses de fevereiro e abril do ano de 2001 e enviadas para a Universidade Federal do Rio Grande do Sul. Nessa região, a espécie daninha floresce entre os meses de janeiro e março e o amadurecimento dos frutos ocorre de fevereiro a abril. Os locais de amostragem apresentavam no mínimo 50 plantas por $\mathrm{m}^{2}$ sobreviventes a aplicação do herbicida.

Os frutos contendo as sementes foram inicialmente armazenados em sacos de papel e, quando estavam devidamente secos, liberaram as sementes que foram armazenadas em temperatura ambiente. Entre 1.000 e 3.000 sementes foram coletadas em no mínimo 20 plantas distribuídas ao acaso na área. Em agosto de 2001, as sementes foram colocadas em vasos com capacidade de $300 \mathrm{~cm}^{3}$, mantidos em casa de vegetação. Sementes de plantas suscetíveis foram usadas no experimento como tratamento controle. Como substrato, utilizou-se a mistura de 33\% de Argissolo 
Vermelho distrófico típico, 33\% de areia e 33\% de turfa. Quando a maior parte das plantas apresentava-se no estágio de quatro folhas, foram aplicados $200 \mathrm{~g} \mathrm{ha}^{-1}$ do herbicida imazethapyr, com adjuvante não iônico $(0,2 \%$ v/v) Todo este procedimento foi repetido duas vezes e apenas as populações com plantas sobreviventes a duas repetições foram identificadas como resistentes. Quarenta populações que apresentavam a resistência ao herbicida foram selecionadas, representando os municípios de Almirante Tamandaré, Augusto Pestana, Bela Vista, Carazinho, Charrua, Chiapeta, Colorado, Coxilha, Cruz Alta, Ijuí, Jóia, Marau, Mato Castelhano, Não-me-Toque, Palmeira das Missões, Pontão, Porto Alegre, Rio Pardo, Saldanha Marinho e Santo Ângelo (Tabela 1).

Amostras de 0,2 g de tecido foliar para extração de DNA foram coletadas em 20 plantas, de cada população, quando apresentavam quatro a cinco folhas. As folhas foram agrupadas, formando um "bulk" de DNA para cada população. O protocolo de extração foi adaptado do método CTAB (brometo de cetiltrimetilamônio) contendo Tris- $\mathrm{HCl} 1 \mathrm{M}$, EDTA $0,5 \mathrm{M}, \mathrm{NaCl} 5 \mathrm{M}$ e $1,1 \%$ de CTAB. Os reagentes SDS 20\%, fenol, clorofórmio:álcool isoamílico $(24: 1 \mathrm{v} / \mathrm{v})$, etanol absoluto e na concentração de $70 \%$ e acetato de amônio $1 \mathrm{M}$ foram utilizados em etapas

Tabela 1. Populações de Euphorbia heterophylla resistentes a herbicidas inibidores da ALS selecionadas a partir de sementes coletadas em municípios do planalto do Estado do Rio Grande do Sul.

\begin{tabular}{ll}
\hline $\mathrm{N}^{\mathbf{0}}$ da população & Município \\
\hline 6,7 e 8 & Bela Vista \\
9,10 e 11 & Pontão \\
12,13 e 14 & Não-me-Toque \\
15 e 16 & Rio Pardo \\
17,18 e 19 & Coxilha \\
20 & Santo Ângelo \\
21 e 22 & Charrua \\
23,24 e 25 & Almirante Tamandaré \\
26,27 e 28 & Saldanha Marinho \\
29,30 e 31 & Colorado \\
33 & Ijuí \\
34 & Marau \\
35 & Augusto Pestana \\
36,37 e 38 & Palmeira das Missões \\
39 & Cruz Alta \\
40 & Jóia \\
41 & Chiapeta \\
42 & Carazinho \\
43 & Porto Alegre \\
45,46 e 47 & Mato Castelhano \\
\hline
\end{tabular}

sucessivas a fim de obter um DNA de qualidade, com leitura da absorbância em espectrofotômetro que variou de 1,7 a 2,0 .

Trinta primers com dez nucleotídeos de seqüência arbitrária foram utilizados para verificar o polimorfismo para a espécie: OPP 05, 06, $07,08,09,10$; OPE 06, 09, 10, 11, 12, 13; OPAF 18, 19, 20; OPAD 01, 02, 04, 08, 09, 10, 11, 17, 18; OPAG 01, 19, 20 e OPAI 14, 19, 20. Reações de amplificação do DNA foram feitas por meio da técnica de PCR (reação em cadeia da enzima polimerase) programado para $1 \mathrm{~min}$ a $94^{\circ} \mathrm{C}$ seguido por 35 ciclos de $1 \mathrm{~min}$ a $94^{\circ} \mathrm{C}$, $1 \mathrm{~min}$ a $35^{\circ} \mathrm{C}$ e $2 \min$ a $72^{\circ} \mathrm{C}$. Uma incubação de $10 \mathrm{~min}$ a $72^{\circ} \mathrm{C}$ foi incluída como passo final. As reações foram preparadas para um volume final de $25 \mu \mathrm{L}$, contendo a solução tampão da enzima Taq DNA polimerase $(20 \mathrm{mM}$ de Tris- $\mathrm{HCl}$ e $50 \mathrm{mM}$ de $\mathrm{KCl}$ ); 0,2 mM de cada dNTP; 1,5 $\mathrm{mM}$ de $\mathrm{MgCl}_{2} ; 0,24 \mu \mathrm{M}$ de primer; $20 \mathrm{ng}$ de DNA; 1,2 unidades da enzima Taq DNA polimerase. Os fragmentos de DNA foram separados por eletroforese em gel de agarose $2 \%$, em solução TBE (Tris-base, ácido bórico, EDTA). Os fragmentos amplificados foram visualizados em gel contendo brometo de etídio, em um transiluminador com radiação ultravioleta. A imagem foi captada por uma câmara digital acoplada ao computador e foi usado o programa Kodak Digital Image.

Avaliou-se a presença ou ausência das bandas. O coeficiente de Jaccard foi usado para a construção da matriz de distâncias genéticas. Considerando-se esses dados, foi elaborado um fenograma pelo método UPGMA de agrupamento hierárquico, com o auxílio do programa computacional NTSYS (Rohlf, 2000).

\section{Resultados e Discussão}

Dos 30 primers selecionados, 27 amplificaram e apresentaram boa reprodutibilidade das bandas. Essas bandas demonstraram polimorfismo e, com isso, a existência de variabilidade genética entre as populações estudadas, sendo estes primers utilizados para a análise de RAPD. Todos os 176 locos avaliados são polimórficos. Os primers OPE 13, OPAI 14 e 19 não apresentaram amplificação de fragmentos e foram descartados da análise.

No presente trabalho, os primers OPAF 18 e OPAF 19 foram polimórficos. Em trabalho similar com E. heterophylla, estes mesmos primers apresentaram comportamento diferenciado quanto ao polimorfismo, sendo o OPAF 19 monomórfico (Vasconcelos et al., 2000). 
Avaliou-se a presença (1) ou ausência (0) de bandas no gel de agarose para todas as populações e primers. As bandas analisadas variaram entre $200 \mathrm{e}$ 2.100 pares de bases (pb). Com base nesta análise, foi possível construir uma planilha de dados no programa Excel para Windows, que permitiu a construção da matriz binária e a identificação dos fragmentos amplificados em maior ou menor frequiência. Os 27 primers utilizados na análise produziram um total de 2.437 bandas. Nas 40 populações, o número de fragmentos gerados por primer variou de 13 a 185, com uma média de 90,26 bandas por primer (Tabela 2). Das 2.437 bandas avaliadas, $18(9,60 \%)$ corresponderam ao fragmento de $900 \mathrm{pb}$, $15(9,43 \%)$ ao fragmento de 600 pb e $16(9,02 \%)$, ao

Tabela 2. Bandas analisadas e tamanho dos fragmentos amplificados para cada primer avaliado ${ }^{(1)}$.

\begin{tabular}{lcc}
\hline Primer & $\begin{array}{c}\mathrm{N}^{\mathbf{0}} \text { de bandas } \\
\text { analisadas }\end{array}$ & $\begin{array}{c}\text { Tamanho dos } \\
\text { fragmentos }(\mathrm{pb})\end{array}$ \\
\hline OPP 05 & 99 & $300-2.000$ \\
OPP 06 & 100 & $550-1.800$ \\
OPP 07 & 72 & $800-1.750$ \\
OPP 08 & 185 & $300-1.500$ \\
OPP 09 & 152 & $350-1.900$ \\
OPP 10 & 95 & $250-1.500$ \\
OPE 06 & 133 & $500-2.000$ \\
OPE 09 & 167 & $200-2.100$ \\
OPE 10 & 105 & $300-1.750$ \\
OPE 11 & 150 & $550-2.000$ \\
OPE 12 & 153 & $400-1.500$ \\
OPAF 18 & 151 & $600-2.000$ \\
OPAF 19 & 111 & $500-900$ \\
OPAF 20 & 34 & $300-1.100$ \\
OPAD 01 & 58 & $600-1.600$ \\
OPAD 02 & 70 & $600-2.000$ \\
OPAD 04 & 50 & $400-1.300$ \\
OPAD 08 & 119 & $500-2.000$ \\
OPAD 09 & 52 & $470-1.000$ \\
OPAD 10 & 98 & $1.100-2.000$ \\
OPAD 11 & 75 & $550-1.500$ \\
OPAD 17 & 27 & 1.300 \\
OPAD 18 & 38 & 900 \\
OPAG 01 & 70 & $400-2.000$ \\
OPAG 19 & 32 & $800-1.600$ \\
OPAG 20 & 13 & $600-2.000$ \\
OPAI 20 & 57 & $1.300-2.000$ \\
\hline Total & 2.437 & $200-2.100$ \\
\hline (1) Á́dia de bandas anlisas por primer foi de 90.26 \\
OPd
\end{tabular}

Pesq. agropec. bras., Brasília, v. 38, n. 9, p. 1067-1072, set. 2003 fragmento de $800 \mathrm{pb}$, constituindo as bandas mais comuns encontradas entre os primers e populações analisadas. Outros fragmentos, no entanto, tiveram menor freqüência, e se manifestaram em populações e primers específicos, como fragmentos de $200 \mathrm{pb}$ e $1.350 \mathrm{pb}$ (ambos 0,04\%) nos primers OPE 9 e OPE 12, correspondendo, respectivamente, às populações 36 (Palmeira das Missões) e 42 (Carazinho), e o fragmento de $470 \mathrm{pb}(0,08 \%)$, primer OPAD 9 e populações 26 e 27 de Saldanha Marinho.

Em um estudo com erva-mate (Ilex paraguaiensis), esta divergência decorrente da frequiência de determinadas bandas foi determinante para estimar a variabilidade entre as populações (Gauer, 1999).

Pela análise de agrupamento hierárquico, as populações foram separadas em sete grupos distintos (Figura 1).

O coeficiente médio de similaridade foi de $40 \%$, um valor muito baixo quando comparado ao de espécies cultivadas. Resultado semelhante foi obtido por Vasconcelos et al. (2000), que encontraram para E. heterophylla um valor de distância genética máximo de $39 \%$, e por Rutledge et al. (2000), que observaram para Echinochloa crus-galli uma distância genética de $43 \%$ entre 16 populações selecionadas. No entanto, acessos de Eichornia crassipes (aguapé) apresentaram similaridade genética de 90\%, considerada alta, o que se explica pela forma de propagação vegetativa, que diminui a possibilidade de recombinação genética (Cardoso et al., 2002).

Foi observado que os sete grupos estão parcialmente isolados reprodutivamente, não sendo verificado, a princípio, fluxo gênico entre eles. Se isto for comprovado em estudos posteriores, facilitará o controle e manejo da dispersão desses focos de resistência. Esta observação foi feita pela análise do comportamento das populações 10 e 11 do Município de Pontão, 35 (Augusto Pestana) e 12 (Não-me-Toque) que são geneticamente diferentes das demais. Supõe-se que a distância geográfica entre elas contribua para este resultado. No entanto, não é possível afirmar ser esta a causa desta variabilidade, uma vez que estudos mais detalhados ainda não foram realizados. 


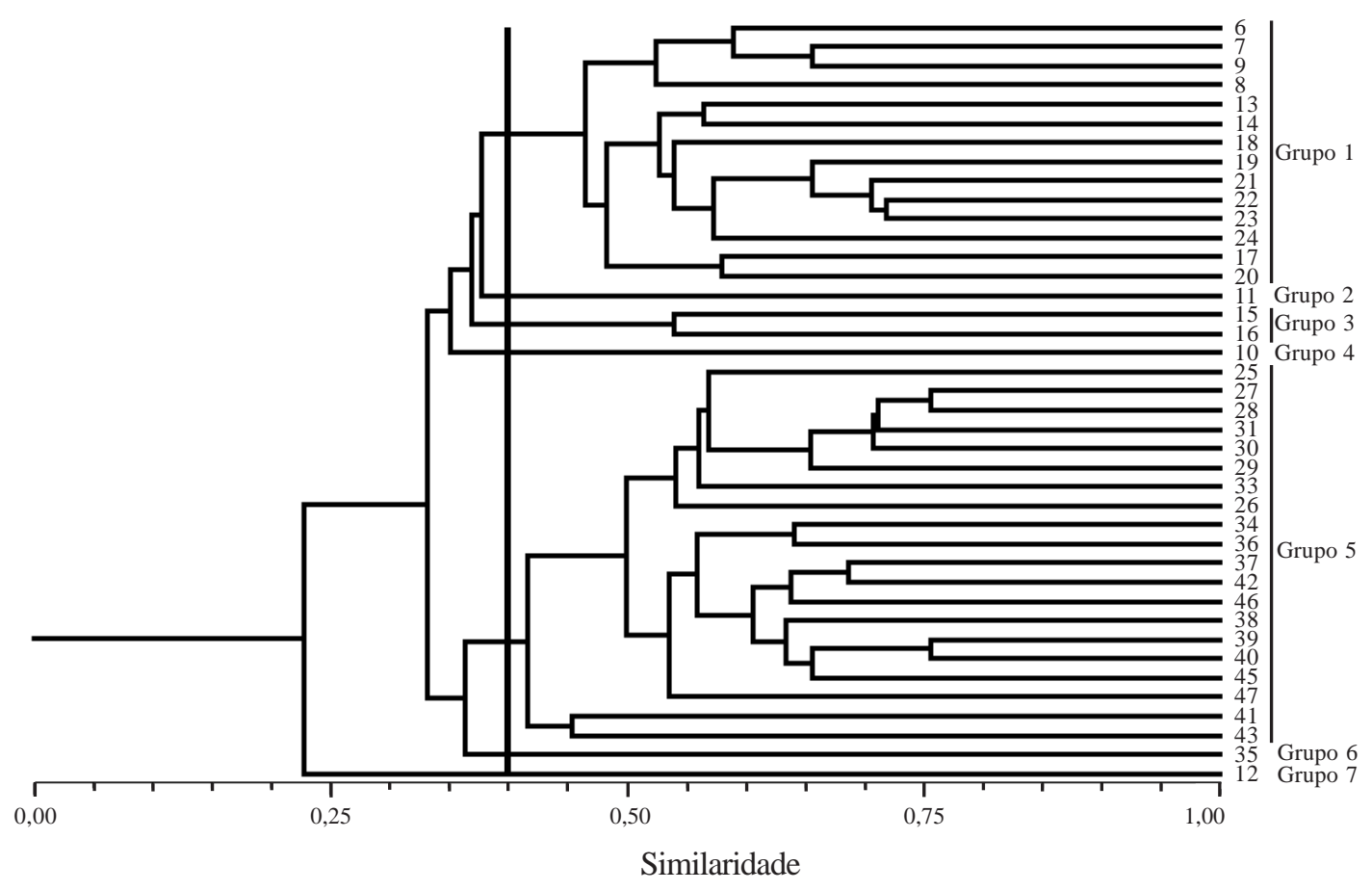

Figura 1. Fenograma de similaridade genética entre 40 populações de Euphorbia heterophylla do Estado do Rio Grande do Sul, com coeficiente médio de similaridade igual a 40\% distribuídas nos grupos 1, 2, 3, 4, 5, 6 e 7 .

As populações de propriedades de um mesmo Município apresentaram similaridade genética, como foi o caso das populações dentro dos grupos 1 e 5. Estes dados sugerem que a dispersão da espécie é limitada. De fato, as sementes de E. heterophylla são liberadas do fruto pelo processo de bolocoria, também conhecido como deiscência explosiva (Kissmann \& Groth, 1992). Supõe-se que até há poucos anos, as sementes de soja comercializadas no Estado do Rio Grande do Sul provinham de uma mesma fonte comercial e, com isso, focos dessa planta daninha podem ter se alastrado geograficamente. Ambas as espécies, soja e leiteira, teriam evoluído em um processo paralelo, favorecendo a seleção de biótipos resistentes aos herbicidas inibidores de ALS em campos de soja, pelo uso intenso de produtos com este mecanismo de ação nos últimos anos.

\section{Conclusão}

Há variabilidade genética quanto à resistência aos herbicidas inibidores da acetolactato sintase entre as populações de Euphorbia heterophylla que ocorrem no planalto do Estado do Rio Grande do Sul.

\section{Agradecimentos}

Ao CNPq, pela concessão da bolsa de recém-doutor; ao CNPq e à Fapergs, pelo apoio financeiro; ao Eng. Agrôn. Gustavo C. Hernandes e ao estudante Israel R. Silva, pelo apoio na condução dos trabalhos em casa de vegetação; ao Eng. Agrôn. Cícero C. de Sousa Almeida, pelo apoio na utilização do programa NTSYS. 


\section{Referências}

CARDOSO, L. R.; MARTINS, D.; KURAMAR, E. E.; TANAKA,R. H.; MORI, E. S. Variabilidade genética de acessos de aguapé coletados no Estado de São Paulo. Planta Daninha, Viçosa, MG, v. 20, p. 1-5, 2002.

CHEMALE, V. M.; FLECK, N. G. Avaliação de cultivares de soja (Glycine max (L.) Merril) em competição com Euphorbia heterophylla L. sob três densidades e dois períodos de ocorrência. Planta Daninha, Campinas, v. 5 , p. 36-45, 1982.

GAUER, L. Variabilidade genética em populações naturais de erva-mate usando marcadores RAPD. 1999. 80 f. Dissertação (Mestrado em Genética e Biologia Molecular) - Universidade Federal do Rio Grande do Sul, Porto Alegre, 1999.

GAZZIERO, D. L. P.; BRIGHENTI, A. M.; MACIEL, C. D. G.; CHRISTOFFOLETI, P. J.; ADEGAS, F. S.;

VOLL, E. Resistência de amendoim-bravo aos herbicidas inibidores da enzima ALS. Planta Daninha, Botucatu, v. 16 , n. 2 , p. $117-125,1998$.

HEAP, I. International survey of herbicide-resistant weeds. Disponível em: 〈http://www.weedscience.com>. Acesso em: 2 de out. 2002.

KISSMANN, K. G.; GROTH, D. Plantas infestantes e nocivas. São Paulo: Basf, 1992. 798 p.

MOODIE, M.; FINCH, P. R.; MARSHALL, G. Analysis of genetic variation in wild mustard (Sinapsis arvensis L.) using molecular markers. Weed Science, Lawrence, v. 45, n. 3, p. 102-107, 1997.

ROHLF, F. J. Numerical taxonomy and multivariate analysis system. Port Jefferson: Applied Biostatistics, 2000. 38 p.

ROWE, M. L.; LEE, D. J.; BOWDITCH, B. M.; MASTERS, R. A. Genetic variation in North American leafy spurge (Euphorbia esula) determined by DNA markers. Weed Science, Lawrence, v. 45, p. 446-454, 1997.
RUTLEDGE, J.; TALBERT, R. E.; SNELLER, C. H. RAPD analysis of genetic variation among propanil-resistant and susceptible Echinochloa crus-galli populations in Arkansas. Weed Science, Lawrence, v. 48, n. 6, p. 669-674, 2000.

SWEENEY, P. M.; DANNEBERGER, T. K. RAPD characterization of Poa annua L. populations in golf course greens and fairways. Crop Science, Madison, v. 35, n. 6, p. 1676-1680, 1995.

VARGAS, L.; BORÉM, A.; SILVA, A. A. Herança da resistência aos herbicidas inibidores da ALS em biótipos da planta daninha Euphorbia heterophylla. Planta Daninha, Viçosa, MG, v. 19, n. 3, p. 331-336, 2001.

VARGAS, L.; SILVA, A. A.; BORÉM, A.; REZENDE, S. T.; FERREIRA, F. A.; SEDIYAMA, T. Resistência de plantas daninhas a herbicidas. Viçosa, MG: UFV, 1999. $131 \mathrm{p}$.

VASCONCELOS, M. J. V.; ABDELNOOR, R. V.; KARAN, D.; ALMEIDA, A. M. R.; OLIVEIRA, M. F.; BARROS, E. G.; MOREIRA, M. A. Variabilidade genética em biótipos de leiteiro de Londrina/PR. Planta Daninha, Viçosa, MG, v. 18, n. 2, p. 285-291, 2000.

VIDAL, R. A.; MEROTTO JÚNIOR, A. Herbicidologia. Porto Alegre: Evangraf, 2001. 152 p.

VIDAL, R. A.; WINKLER, L. M. Resistência de plantas daninhas: seleção ou indução à mutação pelos herbicidas inibidores de acetolactato sintase (ALS). Pesticidas: Revista de Ecotoxicologia e Meio Ambiente, Curitiba, v. 12, p. 31-42, 2002.

WILLIAMS, J. G. K.; KUBELIC, A. R.; LIVAK, K. J.; RAFALSKI, J. A.; TINGEY, S. D. DNA polymorphisms amplified by arbitrary primers are useful as genetic markers. Nucleic Acids Research, Oxford, v. 18, n. 22, p. 6531-6535, 1990.

WINKLER, L. M.; VIDAL, R. A.; BARBOSA NETO, J. F. Aspectos genéticos envolvidos na resistência de plantas daninhas aos herbicidas. Plantio Direto, Passo Fundo, v. 70, n. 4, p. 21-24, 2002. 